\title{
圧力測定孔の周波数特性
}

\section{Frequency characteristics of cavity-mounted pressure sensors}
○ 及川光壱郎（秋田大）
加藤久美子（秋田大）
正 飯村 或郎（秋田大）
正 佐々木芳宏（秋田大）

Kouichiro OIKAWA, Akita University, Tegata-gakuenmachi 1-1, Akita city, Akita

Kumiko KATO, Ikuro IIMURA, Yoshihiro SASAKI, Akita University

Key Words: Cavity-mounted pressure sensor, Frequency characteristics

\section{1.はじめに}

圧力センサの受圧部は通常，若干の大きさを持つ平面であ る為, 細い管路内のような狭い測定箇所または曲がった壁面 などにおいては流れを乱さずにセンサを直接取り付けること は困難なことが多い.

このような場合には Fig.1 のように測定部の壁面に小孔を 開け，さらにセンサ受圧面が十分収納できる空洞を設けそこ に導かれた圧力が測定される.この小孔を検出孔，空洞を受 圧室と呼び，それらをまとめて圧力測定孔または測圧孔と呼 ぶ. 測圧孔は上述のほかにセンサ受圧面の保護やノイズ成分 にたいする遮断要素（フィルタ）としても利用される.

しかし，測圧孔を介して測定された圧力信号は，センサ受 圧面で直接検出しないことにより測定誤差が生ずるという久 点がある。

そこで，測圧孔により検出された出力波形から正しい圧力 波形を推定するために，測圧孔の周波数特性を知ることは不 可欠になる. 通常, 検出孔の直径と長さは同程度である.

しかし，センサを測定部の近くに取り付けることができな いことが多く，その場合には受圧面自体の検出孔を長くする 場合がある。そこで，本研究では，検出孔の長さによる周波 数特性の変化を実験により求め, 検出孔が短い(オリフィスモ デル)場合の理論值と長い(管路モデル)場合の理論値と比較し て，两モデルの予测精度を検討する．

\section{2. 理論式}

2-1 オリフィスモデル

Fig.1において, 真の圧力を $p_{1}$, 受圧室圧力を $p_{2}$ とする. 検出孔を通る非定常な体積流量を $q$ とする. Fig.1 を等価回路 で表すと同図右のようになる。

検出孔による流体抵抗, 流体イナータンスをそれぞれ $R$ と

$L$, 受圧室容量を $C$ とすると次の式が成り立つ ${ }^{1)}$.

$$
L C \frac{d^{2} p_{2}}{d t^{2}}+R C \frac{d p_{2}}{d t}+p_{2}=p_{1}
$$

L，Cはそれぞれ

$$
L=\frac{\rho l_{1}}{A_{1}}\left(1+\frac{8}{3 \pi} \frac{d_{1}}{l_{1}}\right) \equiv \frac{\rho l_{1}}{A_{1}} k
$$
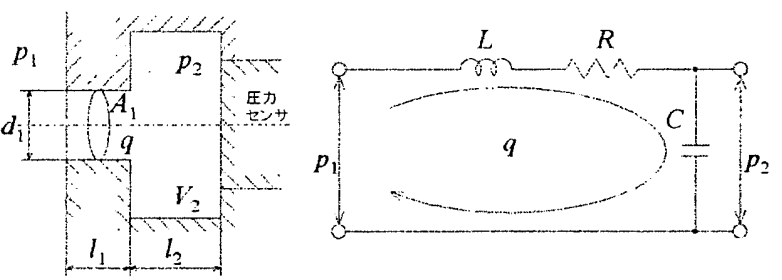

Fig. 1 測圧孔（オリフィスモデル）と等価回路
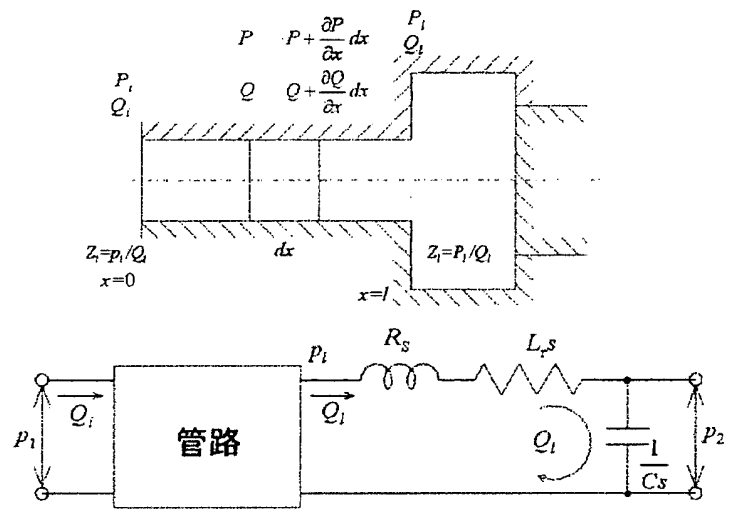

Fig. 2 測圧孔（管路モデル）と等価回路

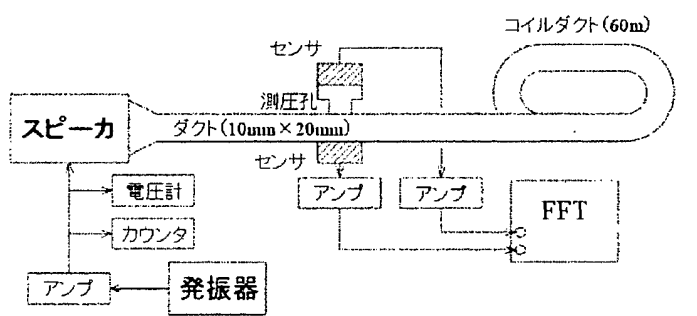

Fig. 3 実験装置概略

$$
C=\frac{V_{2}}{\rho c^{2}}
$$

また流体抵抗 $R$ は,

$$
R=\frac{8}{3 \pi} \frac{\rho}{2 C_{d 0}^{2} A_{1}^{2}} \frac{V_{2}}{\rho c^{2}} \omega p_{1 m} M+k_{s} \frac{8 \pi \rho \nu l_{1}}{A_{1}^{2}}
$$

これらの式より $L$ は検出孔の長さと直径に， $C$ は受圧室の容 積に， $R$ は主に検出孔の直径と圧力振幅に依存していること がわかる。 


\section{2-2 管路モデル ${ }^{2)}$}

次に検出孔が長い管路状の場合について考える. Fig.3にお いて管路の微小長さを $d x$ とし, 圧力 $p(x, t)$ と流量 $q(x, t)$ が微小 で，かつ $x$ とのみの関数であるとすれば

$$
\begin{aligned}
& \frac{\partial P(x, s)}{\partial x}=-Z(s) Q(x, s) \\
& \frac{\partial Q(x, s)}{\partial x}=-Y(s) P(x, s)
\end{aligned}
$$

と示される， $Z(\mathrm{~s}) ， Y(\mathrm{~s})$ はそれぞれ単位長さあたりのインピ ーダンスおよびアドミッタンスである. (s はラプラス演算子)

上式より単位長さあたりの伝播定数 $\Gamma$, 特性インピーダン ス $\mathrm{Z}_{*}$ は以下のようになる.

$$
\Gamma(s)=\sqrt{Z Y} \quad, \quad Z *(s)=\sqrt{\frac{Z}{Y}}
$$

したがって

$$
\begin{aligned}
& \frac{P}{P_{l}}=\cosh \Gamma(l-x)+\frac{Z_{*}}{Z_{L}} \sinh \Gamma(l-x) \\
& \frac{Q}{Q_{l}}=\frac{Z_{L}}{Z_{*}} \sinh \Gamma(l-x)+\cosh \Gamma(l-x)
\end{aligned}
$$

ただし， $Z_{\mathrm{L}} \equiv P_{l} / Q_{l}$ は負荷インピーダンスである. $x=0$ で $P=P_{\mathrm{i}}, Q=Q_{\mathrm{i}}$ とすると, $x=0 \sim l$ までの圧力伝達関数は

$$
\begin{aligned}
& \frac{P_{l}}{P_{i}}=\frac{1}{\cosh \Gamma l+\left(Z_{*} / Z_{L}\right) \sinh \Gamma l} \\
& \frac{Q_{l}}{Q_{i}}=\frac{1}{\cosh \Gamma l+\left(Z_{L} / Z_{*}\right) \sinh \Gamma l}
\end{aligned}
$$

である。また流体圧管路の $Z$ と $Y$ は

$$
\begin{aligned}
& Z=\frac{\rho s}{A_{1}}\left[1-\frac{2 J_{1}(j a \sqrt{s / v})}{j a \sqrt{s / v} J_{0}(j a \sqrt{s / v})}\right]^{-1} \\
& Y=\frac{A_{1} s}{\rho c^{2}}\left[1+\frac{2(\gamma-1) J_{1}(j a \sqrt{\sigma s / v})}{j a \sqrt{\sigma s / v} J_{0}(j a \sqrt{\sigma s / v})}\right]
\end{aligned}
$$

ここで $J_{0}, J_{1}$ それぞれ 0 次, 1 次のベッセル関数, $\gamma$ は気体の 比熱比， $\sigma$ はプラントル数を表す.

よって管路モデルにおううる圧力伝達関数は次式で表される.

$$
\frac{P_{2}}{P_{1}}=G=\frac{1}{\cosh \Gamma l_{1}+\frac{Z_{*}}{Z_{L}} \sinh \Gamma l_{1}} \cdot \frac{1}{Z_{L} C s}
$$

\section{3. 実験}

実験装置の概略を Fig.3 に示す. 本研究に用いた測圧孔の寸 法は, 検出孔の直径 $d_{1}$ が $0.5 \mathrm{~mm}$, 長さ $l_{1} か ゙ ~ 0.5,1,2,4,8$, $16 \mathrm{~m} \mathrm{mmm}$, 受圧室の直径 $d_{2}$ が $7 \mathrm{~mm}$, 深さ $l_{2}$ が, $4 \mathrm{~mm}$ である. 圧力測定孔の材質は黄銅で, $7 \mathrm{~mm}$ という直径は使用する圧力 センサの受圧面直径 $5 \mathrm{~mm}$ 適合するように定めた。また， 受圧面と受圧室底面は同一平面になるように取り付けた。
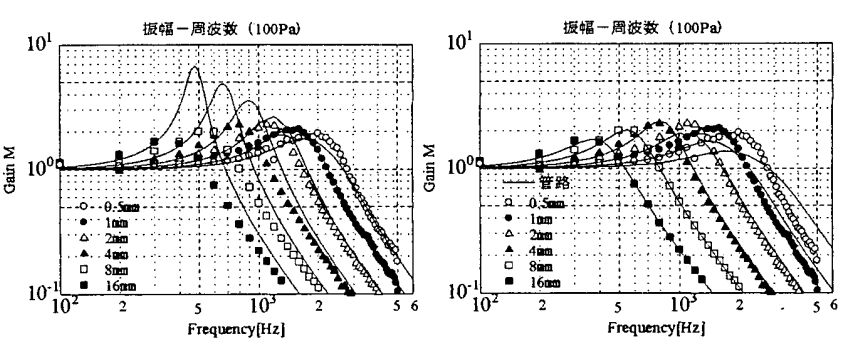

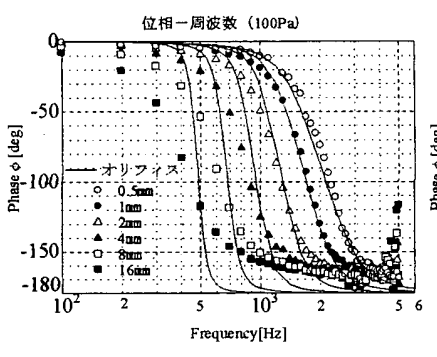

(a)オリフィスモデル

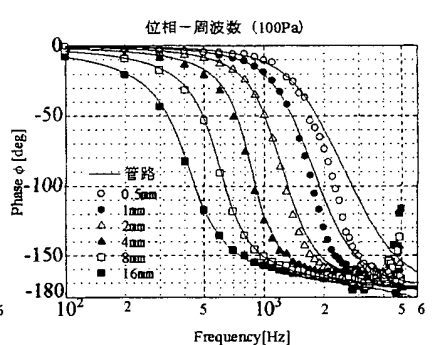

(b)管路モデル
Fig. 4 実験結果

実験は検出孔の長さと圧力振幅の影響を測定しシミュレー ションによる理論值と実験值との比較を行った.

\section{4. 結果および考察}

Fig.4より, 検出孔 $l_{1}$ が長くなるほど共振周波数が低くなっ ているのがわかる. また, 位相ずれは比較的低周波域から生 じ始めている.これはいずれも, 測圧孔の固有周波数 $\omega_{\mathrm{n}}$ がお おむね検出孔 $l_{1}$ の平方根に反比例している為と考えられる.

検出孔の長さが短い場合，共振点付近において圧力振幅の 影響が見られる.これは共振点付近で検出孔を通る流量振幅 が増大し，これにより抵抗 Rが大きくなるためゲインが小さ くなるためと考えられる.

位相差について，オリフィスモデルでは実験值とずれがあ るが管路モデルにおいてはほぼ近い值が得られている.

検出孔の長さが短い場合はオリフィスモデルと, 長い場合 には管路モデルの理論値とよく一致していることがわかる.

\section{5. 結言}

検出孔の長さと圧力振幅が測圧孔の周波数特性にどのよう な影響を与えるのかを管路の信号伝達理論を用いた理論と実 験により検討した.

測圧孔の長さが長くなるほど，共振周波数のピーク值は低 くなり，位相のずれが低い周波数から生じている．また，共 振点での圧力振幅の影響はほとんどなくなることが示される。 理論值については, 実験值とほぼ近い值を求めることがで きたので精度はよいと考えられる。

\section{参 考 文 献}

1）飯村 或郎：圧力測定孔の動特性に関する研究, 東北大 学博士学位論文(1992)

2）下日向 正行: 圧力測定孔の周波数特性, 秋田大学工学 資源学部機械工学科平成 14 年度卒業論文(2003) 